\title{
Defoliation impacts on Festuca campestris (Rydb.) plants exposed to wildfire
}

\author{
AMANDA D. BOGEN ${ }^{1}$, EDWARD W. BORK, AND WALTER D. WILLMS
}

Authors are Rangeland Ecologist, Box 484, Consort, Alberta, Canada T0C 1B0; Assistant Professor, Dept. of Agr., Food and Nutr. Sci., University of Alberta, Edmonton, Alberta, Canada T6G 2P5 and Range Scientist, Agr. and Agr. Food Canada, P.O. Box 3000, Lethbridge, Alberta, Canada T1J 4B1. At the time of the research, the senior author was a Research Assistant, Dept. of Agr., Food and Nutr. Sci., University of Alberta.

Abstract

Wildfires commonly occur in the Fescue Prairie of Alberta, but little information exists to provide a basis for making grazing recommendations after burning. A wildfire in April 1999 provided an opportunity to study the effect of season and intensity of post-burn defoliation on foothills rough fescue $(F$. campestris Rydb.) in southwestern Alberta. A 3 (date of defoliation) $x 2$ (defoliation intensity) factorial experiment with 10 replicates (plants) was established in both a burned and a non-burned grassland and analyzed as a nested design. Plants were defoliated once during active vegetative growth (17 May), inflorescence development ( 2 July), or dormancy (30 September), at either 5 or 15-cm clipped stubble heights in the first growing season after fire. Burning increased tiller numbers by $54 \%$ compared to nonburned plants but reduced plant ANPP by $51 \%$ in the second growing season. While a single defoliation of burned plants, particularly early in the year, had little effect on growth, delaying defoliation into July decreased tillers 1 year later. Increasing defoliation intensity had the greatest impact on non-burned plants, reducing plant height $(\mathbf{1 5 \%})$ as well as tiller $(\mathbf{2 1 \%})$ and plant $(32 \%)$ ANPP in the second year. May defoliation reduced etiolated growth 1 year later regardless of burn treatment. A single grazing event after wildfire does not necessarily appear to detrimentally affect rough fescue; however, the low herbage available immediately after fire may not justify the increased risk to the plant with subsequent grazing.

Key Words: defoliation intensity, deferment, etiolated growth, herbage yield, resilience, tillers

The Fescue Prairie of the Northern Great Plains is characterized by the occurrence of plains rough fescue [Festuca hallii (Vasey) Piper] and foothills rough fescue ( $F$. campestris Rydb) in the prairie-parkland and foothill regions, respectively. Plains rough fescue is shorter than foothills rough fescue and produces short rhizomes compared with the strongly tufted habit of the latter (Pavlick and Looman 1984). Most fire ecology studies in the Fescue Prairie have been conducted in the Parkland (Bailey and Anderson 1978, Anderson and Bailey 1980, Redmann et al. 1993, Gerling et al. 1995). Although the foothills species of rough fes-

The authors would like to thank the Alberta Cattle Commission and the Range Management Post-Graduate Endowment Fund at the University of Alberta for funding this research. Special thanks are extended to Albert Middleton and Ryan Beck for their assistance with fieldwork, as well as Dr. Peter Blenis for statistical advice. The authors are also grateful to George Powell and 2 anonymous reviewers, who provided helpful comments on an earlier version of the manuscript.

Manuscript accepted 26 Aug. 02.

\section{Resumen}

Comúnmente ocurren fuegos naturales en las praderas de "Fescue" de Alberta, pero existe poca información en que basar las recomendaciones de apacentamiento después del fuego. Un fuego natural que ocurrió en Abril de 1999 brindó la oportunidad para estudiar el efecto de la época e intensidad de defoliación después del fuego en una pradera de "Foothills rough fescue" ( $F$. campestris Rydb.) del sudeste de Alberta. Un experimento factorial 3 (fecha de defoliación) $x 2$ (intensidad de defoliación) con 10 repeticiones (plantas) se estableció en porciones de pastizal quemado y no quemado y se analizó como un diseño anidado. Las plantas fueron defoliadas una vez en las etapas de crecimiento vegetativo activo (17 de Mayo), desarrollo de la inflorescencia ( 2 de Julio) o dormancia ( 30 de Septiembre), la defoliación se efectuó a dos alturas del rastrojo, 5 o $15 \mathrm{~cm}$, y se llevo a cabo en la primer estación de crecimiento después del fuego. El fuego aumento el número de hijuelos en $54 \%$ en comparación con las plantas no quemadas, pero redujo la ANNP de las plantas en $51 \%$ en la segunda estación de crecimiento. Mientras que una sola defoliación de las plantas quemadas, particularmente a inicio del año, tuvo poco efecto en el crecimiento, retasando la defoliación hasta Julio disminuyo el ahijamiento en el año siguiente. El aumento en la intensidad de defoliación tuvo el mayor impacto en las plantas no quemadas, reduciendo en el segundo año la altura de la planta (15\%), el ahijamiento (21\%) y la ANPP de la planta (32\%). La defoliación en Mayo redujo el crecimiento etiolado al año siguiente, sin importar el tratamiento de quema. Un solo evento de apacentamiento después de un fuego natural no necesariamente parece tener un efecto detrimental en el "Rough fescue"; sin embargo, el poco forraje disponible inmediatamente después del fuego, puede no justificar el aumento en riesgo para la planta que se corre con el apacentamiento subsecuente.

cue might be expected to have a similar response to fire, this premise remains untested.

Rough fescue loses vigor when grazed during the growing season (Looman 1969). Burning may reduce rough fescue abundance (Bailey and Anderson 1978, Antos et al. 1983) and productivity (Jourdonais and Bedunah 1990, Gerling et al. 1995). While considerable research has addressed the effects of grazing on Fescue Prairie (Barker and Erickson 1971, Wright 1974, Willms et al. 1985), no information is available on the cumulative effects of grazing following wildfire on foothills rough fescue plants. Previous research has shown that grazing can affect the subsequent recovery of native bunchgrasses such as Idaho fescue ( $F$. idahoensis Elmer) and bluebunch wheatgrass [Pseudoroegneria spicata (Pursh) A. Löve subsp. Spicata] after wildfire (Bunting et 
al. 1998). Recent increases in wildfire occurrence in the Fescue Prairie (Bork et al. 2002) indicate information specific to foothills rough fescue is needed to develop appropriate guidelines for grazing following fire.

In April 1999, a small wildfire in the Foothills region of Alberta provided an opportunity to study the effects of defoliation following burning on foothills rough fescue plants. The study was specifically designed to evaluate the resilience of plants subjected to variation in the season and intensity of defoliation over a 2 year period.

\section{Materials and Methods}

\section{Site Description}

The study was conducted in southwestern Alberta $\left(50^{\circ} 11^{\prime} 30^{\prime \prime} \mathrm{N}, 113^{\circ} 53^{\prime} 30^{\prime \prime} \mathrm{W}\right.$; $1,366 \mathrm{~m}$ above sea level) within the Fescue Prairie ecoregion on the eastern slopes of the Porcupine Hills (Strong and Leggat 1992). The area was lightly grazed from 1949 until 1982 when it was fenced to exclude livestock. The plant community was a foothills rough fescue-Parry oat grass (Danthonia parryi Scribn.) type indicative of the modal range for the region (Wroe 1972, Strong and Leggat 1992).

The regional landform is rolling moraine upland. The local range site had a slope of approximately $8 \%$ with a southerly aspect and is well-drained on loamy parent material. Soils on the site have been classified as Orthic Black Chernozems (Udic Haploboral) developed on till over-lying sandstone (Dormaar and Willms 1990). The climate is dry subhumid with a mean annual precipitation of $444 \mathrm{~mm}$ (Table 1). In 1999 and 2000, annual precipitation was 399 and $264 \mathrm{~mm}$, respectively. Growing season (April-August) precipitation during those same years was $123 \%$ $(351 \mathrm{~mm})$ and $60 \%(171 \mathrm{~mm})$, respectively, of the long-term mean.

\section{Wildfire Description}

The study site was burned by a 1-ha wildfire around 2 pm on 7 April 1999. The average daily wind speed on the day of the fire was $30 \mathrm{~km}$ hour $^{-1}$ (AAFC, unpublished climate data) and air temperatures averaged $6.7^{\circ} \mathrm{C}$ with a low of $0.9^{\circ} \mathrm{C}$ and a high of $13^{\circ} \mathrm{C}$. Relative humidity in the morning was $50 \%$, dropping to $30 \%$ at the time of the fire. The litter fuel load in the area was assessed at $6,372 \mathrm{~kg} \mathrm{ha}^{-1}$ in 1999 (AAFRD-Public Lands Division, unpublished data). The fire occurred immediately following snowmelt but before the initiation of plant growth. Although only a small area was burned, the fire was intense and inflicted considerable visible damage (e.g., pitting) to rough fescue tussocks.

Although this study involved a single burn and is therefore unreplicated, variability in fuel loading and microclimatic conditions at the ground surface typically results in variable treatment exposure among individual plants, which was considered the experimental unit in this investigation. Immediate containment of the fire on the windward side ensured that rough fescue plants sampled on either side of the fire boundary were on the same range site.

\section{Methodology}

The effects of defoliation intensity following burning were evaluated in a 3 (season of defoliation) $\mathrm{x} 2$ (defoliation intensity) factorial experiment using 10 replicates (plants) of each treatment combination within each of the burned and non-burned areas. Rough fescue plants $(\mathrm{N}=120)$ having a diameter of 15 to $20 \mathrm{~cm}$ near the base were randomly selected from within the burned and adjacent non-burned areas following the fire and permanently marked.

Defoliation dates were 17 May (active vegetative growth), 2 July (inflorescence development), or 30 September (dormant). Defoliation intensities were 5 and $15-\mathrm{cm}$ clipped stubble heights. All defoliation treatments were imposed only during
1999, the first growing season following fire, by clipping to the prescribed height. Harvested phytomass was oven-dried and weighed to determine defoliation intensity. An additional 10 plants were randomly selected in each of the burned and nonburned areas for measurement to serve as a check. These plants were added for qualitative comparisons only and were not part of the main design.

In spring 2000, 2 of 10 plants from each treatment were assessed for etiolated growth. Prior to spring green-up, all standing dead plant material was removed to a $5-\mathrm{cm}$ stubble height. Cones were then placed over these plants down to soil around the outside base to exclude light and all etiolated growth clipped bi-weekly to ground level commencing 2 May until growth ceased. All harvested material was oven-dried and weighed.

Tiller counts were made on all plants in September 1999 at the time of the final defoliation treatments. These counts were subsequently repeated on all non-etiolated plants in the third week of May, second week of July, and last week of September 2000 , in order to assess the residual treatment effects of burning and defoliation on tiller demography throughout the following growing season. Inflorescences were counted in July 1999 on all plants defoliated earlier in May and of all plants marked for defoliation in September. In addition, inflorescences were counted on all non-etiolated plants in July 2000. Plant heights were measured at the same time as tiller counts were undertaken on all undefoliated plants in 1999 (i.e., September) to assess the effect of burning alone, and of all plants in 2000. Plant height was measured as the average extended length of tillers. Maximum above-ground net primary production (ANPP) was harvested near ground level on 30 September, 2000, oven-dried, and weighed. Average tiller weights (mg tiller $^{-1}$ ) were determined for each plant using ANPP and tiller count data.

Table 1. Winter (January to March, November to December), monthly growing season, and 40-year average precipitation on the Fescue Prairie AAFC sub-station near Stavely, Alberta, from 1997 to 2000.

\begin{tabular}{|c|c|c|c|c|c|c|c|c|c|c|}
\hline Year & Jan-Mar & April & May & June & July & Aug. & Sept. & Oct. & Nov-Dec & Total \\
\hline 1997 & 21.9 & 21.4 & 138 & 73.1 & 28 & 77 & 34.9 & 0.2 & 4.9 & 399.4 \\
\hline 1998 & 47.5 & 27.9 & 169.6 & 186.9 & 129.7 & 16.2 & 25.3 & 12.5 & 31.9 & 647.5 \\
\hline 1999 & 10.9 & $66.2^{1}$ & 71.6 & 109 & 53.9 & 50.3 & 15.6 & 8.6 & 12.6 & 398.7 \\
\hline 2000 & 23 & 27 & 16.6 & 66.2 & 13.1 & 48.1 & 59.9 & 1.6 & 8 & 263.5 \\
\hline $\begin{array}{l}40-y r \\
\text { average }\end{array}$ & $76.2^{2}$ & $27.2^{2}$ & 61.8 & 84.1 & 56.1 & 56.8 & 40.8 & 22.6 & $44.8^{2}$ & $444.3^{2}$ \\
\hline
\end{tabular}

Indicates time of wildfire, 7 April 1999.

${ }^{2}$ Data from the Claresholm Meadows Creek, Alberta climate station, 1961-1990 (Environment Canada 1998). 


\section{Statistical Analyses}

All data were analyzed using a split-plot design (Steel et al. 1997). Given the lack of replication of fire, burn treatment was considered the whole plot, with defoliation regimes nested within individual burn treatments. Analysis was done using ANOVA (Proc GLM, SAS Institute Inc. 1991), with an emphasis on defoliation and burn by defoliation effects. Where significant results were found, comparisons were made among seasons and/or intensities of defoliation within individual burned and non-burned treatments. Fescue plant responses examined included phytomass removed in 1999, ANPP levels and maximum plant height in 2000 , as well as tiller and inflorescence numbers in 1999 and 2000. Probability values for the differences of the least-square-means were adjusted for multiple comparisons according to Tukey's procedure. Inflorescence numbers were analyzed as percent of total tillers to adjust for unequal tiller numbers per plant. Tiller count and weight data were normalized using a square root transformation to meet the conditions of normality based on the Shapiro-Wilk statistic and homogeneity of variance based on Levene's test (Steel et al. 1997).

To evaluate changes in tiller demographics, the percentage change in tiller numbers per plant was analyzed using a repeated measures multivariate analysis of variance (MANOVA, SAS Institute Inc. 1991). This procedure tested for the pattern of correlation between treatment effects and seasonal changes in rough fescue tiller numbers based on sequential sampling from September 1999 through May, July, and September of 2000. The process of evaluating percent changes in tiller numbers through time also circumvented the problem that initial, pre-wildfire tiller counts were not available for use as a covariate. Data on percent change in tillers per plant were also normalized using a square root transformation.

\section{Results}

\section{First-Year Effects}

Phytomass yields in the first growing season after burning (1999) were partly an artifact of the nature of the harvesting treatments and did not reflect a plant response to clipping (Tables 2 and 3 ). Nevertheless, the observations provide an opportunity to compare growth and associated opportunities for livestock grazing, as defined by the harvest date, between burned and non-burned plants when cut at
Table 2. Interactive effects of spring wildfire, season of clipping, and clipping height on plant and tiller characteristics of Festuca campestris plants $(n=10)$ in September 1999. Analysis of phytomass harvested and tiller numbers performed on square root transformed data.

\begin{tabular}{|c|c|c|c|c|c|}
\hline \multirow[b]{2}{*}{ Factor } & \multirow[b]{2}{*}{$\mathrm{df}$} & \multicolumn{2}{|c|}{ Phytomass Harvested } & \multicolumn{2}{|c|}{ Tillers } \\
\hline & & $\begin{array}{c}\text { Tillers } \\
\left(\mathrm{mg} \bullet \text { tiller }^{-1}\right)\end{array}$ & $\begin{array}{c}\text { Plant } \\
\left(\mathrm{g} \bullet \text { plant }^{-1}\right)\end{array}$ & $\begin{array}{c}\text { Total } \\
\left(\text { no } \bullet \text { plant }^{-1}\right)\end{array}$ & $\begin{array}{c}\text { Inflorescence }^{1} \\
(\% \text { of total) }\end{array}$ \\
\hline & & --.--- & -Probabilities & --- & --------- \\
\hline Burn (B) & 1 & N/a & N/a & $\mathrm{N} / \mathrm{a}$ & $\mathrm{N} / \mathrm{a}$ \\
\hline Season of Clipping (S) & 2 & $<0.001$ & $<0.0001$ & 0.03 & 0.25 \\
\hline Clipping Height $(\mathrm{H})$ & 1 & $<0.001$ & $<0.0001$ & 0.19 & 0.01 \\
\hline B x S & 2 & 0.12 & $<0.001$ & 0.08 & 0.74 \\
\hline $\mathrm{B} \times \mathrm{H}$ & 1 & 0.88 & 0.15 & 0.81 & 0.01 \\
\hline $\mathrm{S} \times \mathrm{H}$ & 2 & 0.02 & 0.03 & 0.43 & - \\
\hline $\mathrm{B} \times \mathrm{S} \times \mathrm{H}$ & 2 & 0.18 & 0.70 & 0.59 & - \\
\hline
\end{tabular}

Analysis of \% reproductive tillers per plant is based only on spring defoliated and non-defoliated plants due to interference of July clipping with inflorescence production (d.f. $=1$ for all variables tested). the same stubble height. Burned plants had tiller and plant phytomass levels that were 69 and $51 \%$ lower, respectively, than nonburned plants (Table 3 ). Burned plants also exhibited a marked reduction in spring growth leading to a burn by season interaction $(\mathrm{P}<0.001)$, which was reflected in lower herbage yields throughout the year. For example, burned plants harvested in May and September yielded only 4 and $41 \%$ the phytomass of their nonburned counterparts, respectively (Table 3). As expected, defoliation later into the year increased harvested yields $(\mathrm{P}<$ $0.001)$, particularly at the 5-cm clipping height (Table 3).

The reduction of plant and tiller phytomass after burning was associated with a reduction in plant height by September 1999 , from an average of $54( \pm 5)$ to 25 $( \pm 4) \mathrm{cm}$. Although burning had little effect on tiller numbers at the end of the first growing season, tillering was significantly altered by the phenological stage when defoliation occurred $(P=0.03)$. Tiller counts taken in September indicated that plants harvested in May (active vegetative growth), July (inflorescence development), and September (dormancy) had an average of 120,98 , and 128 tillers, respectively, with burned and non-burned plants responding in a similar manner $(\mathrm{P}=0.08)$.

In 1999, inflorescence production was also affected by a burn by clipping height interaction $(\mathrm{P}=0.01)$. Burned plants produced few seedheads regardless of clip-
Table 3. Phytomass harvested at 3 dates and 2 stubble heights from burned and non-burned Festuca campestris plants $(n=10)$ during the first growing season (1999) after spring wildfire. Results of ANOVA are given in Table 2.

\begin{tabular}{|c|c|c|}
\hline Treatment & Tiller Phytomass & Plant Phytomass \\
\hline$\overline{\text { Burn } x \text { Season of Clipping }}$ & $\left(\mathrm{mg} \cdot\right.$ tiller $\left.^{-1}\right)$ & $\left(\mathrm{g} \cdot\right.$ plant $\left.^{-1}\right)$ \\
\hline \multicolumn{3}{|l|}{ Burn } \\
\hline May & 6.4 & $0.4 c^{1}$ \\
\hline July & 23.5 & $2.9 \mathrm{~b}$ \\
\hline Sept & 61.7 & $5.3 \mathrm{a}$ \\
\hline Pooled Mean & 30.6 & 2.9 \\
\hline \multicolumn{3}{|l|}{ Non-burned } \\
\hline May & 99.1 & $9.0 \mathrm{~b}$ \\
\hline July & 82.4 & $10.7 \mathrm{ab}$ \\
\hline Sept & 115.8 & $13.0 \mathrm{a}$ \\
\hline Pooled Mean & 99.1 & 10.9 \\
\hline Interaction SE mean & 10.2 & 0.9 \\
\hline \multicolumn{3}{|c|}{ Clipping Height $x$ Season of Clipping } \\
\hline \multicolumn{3}{|l|}{$5-\mathrm{cm}$} \\
\hline May & $67.1 \mathrm{~b}^{2}$ & $5.7 c^{2}$ \\
\hline July & $67.2 \mathrm{~b}$ & $8.8 \mathrm{~b}$ \\
\hline Sept & $128.1 \mathrm{a}$ & $12.9 \mathrm{a}$ \\
\hline \multicolumn{3}{|l|}{$15-\mathrm{cm}$} \\
\hline May & $38.4 \mathrm{a}$ & $3.7 \mathrm{~b}$ \\
\hline July & $38.6 \mathrm{a}$ & $4.8 \mathrm{a}$ \\
\hline Sept & $49.4 \mathrm{a}$ & $5.4 \mathrm{a}$ \\
\hline Interaction SE mean & 10.2 & 0.9 \\
\hline
\end{tabular}

${ }^{T}$ Within a column and burn treatment, means followed by the same letter do not differ significantly $(\mathrm{P}>0.05)$.

${ }^{2}$ Within a column and clipping height, means followed by the same letter do not differ significantly $(\mathrm{P}>0.05)$ 
Table 4. Interactive effects of burning, season of clipping, and clipping height on plant and tiller characteristics of Festuca campestris in September 2000 following exposure to spring wildfire and subsequent defoliation in $1999(\mathbf{n}=\mathbf{8}$, except for etiolated growth, where $n=2)$. Analysis for tillers and ANPP performed on square root transformed data.

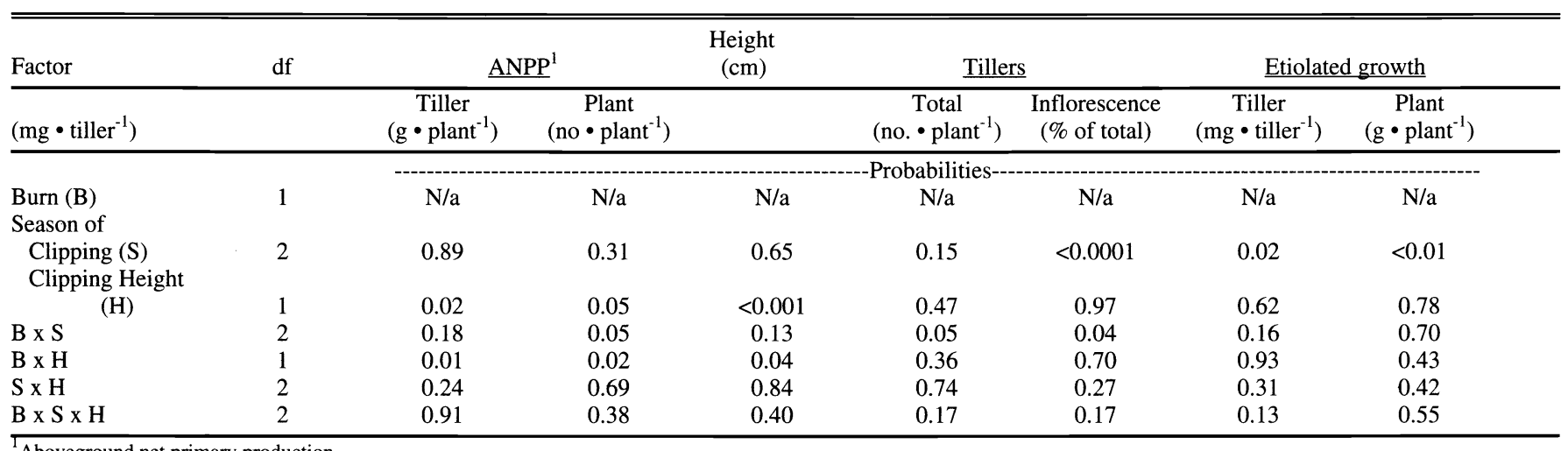

Aboveground net primary production.

ping height $(<0.11 \%$ of tillers $)$, while plants not exposed to fire but clipped at 5 and $15-\mathrm{cm}$ stubble heights had 0.43 and $1.76 \%$ of their tillers produce an inflorescence, respectively.

\section{Second-Year Effects}

Responses in 2000 represented residual effects of defoliation in 1999 (Table 4). In 2000 , burned plants continued to have lower tiller and plant yields (i.e. ANPP) compared to non-burned plants, by 69 and $51 \%$, respectively (Table 5). The observed reduction in plant ANPP in September of 2000 with burning coincided with a continued reduction in plant height $(58 \%$ of nonburned; Table 5) and tillers that weighed $32 \%$ that of non-burned tillers (Table 5). Burned plants remained about $60 \%$ the height of non-burned plants throughout the summer of 2000 (data not shown).

In contrast to these results, burned fescue plants had greater tiller numbers (203 tillers plant $^{-1}$ ) compared to those not exposed to fire (132 tillers plant $\left.{ }^{-1}\right)$. While the increase in tillers within burned plants occurred primarily before May 2000 (Fig. 1), tiller emergence in non-burned plants was most abundant between May and July of 2000.

Plants defoliated to a $5-\mathrm{cm}$ height in 1999 had reduced tiller $(P=0.02)$ and plant ANPP $(\mathrm{P}=0.05)$, as well as plant height $(P<0.001)$ in 2000 . These effects, however, were confined to non-burned plants $(\mathrm{P}<0.05$, Table 5$)$, suggesting burning reduced the impact of the intensive clipping treatment.

Variation in the response of plants to different seasons of clipping was also evident within the burn treatments $(P=0.05)$. Examination of these data indicated ANPP levels were stable among non-burned plants defoliated at different times the year before (Table 5). In contrast, defoliation of burned plants in July resulted in the lowest plant ANPP the following year, although post-hoc mean comparisons revealed no significant difference (at $\mathrm{P}=0.05$ ). Yearend tiller numbers in 2000 also varied among the seasonal defoliation treatments within the burned and non-burned plants $(P=0.05)$. Defoliation of non-burned plants prior to September 1999 stimulated tillering the following year $(140,140$, and 118 tillers plant $^{-1}$, with May, July, and September defoliation, respectively), but depressed tillering if applied in July to burned plants $(234,168$, and 207 tillers plant $^{-1}$, with May, July, and September defoliation, respectively). Tiller numbers

Table 5. Effects of different clipping heights and seasons of defoliation on the mean height and ANPP of burned and non-burned rough fescue plants $(n=8)$, as measured in September 2000 following spring wildfire and defoliation in 1999. ANOVA results are given in Table 4.

\begin{tabular}{|c|c|c|c|}
\hline Treatment & $\begin{array}{l}\text { Plant Height } \\
(\mathrm{cm})\end{array}$ & $\begin{array}{l}\text { Tiller ANPP } \\
\left(\mathrm{mg} \cdot \text { tiller }^{-1}\right)\end{array}$ & $\begin{array}{c}\text { Plant ANPP } \\
\left(\mathrm{g} \cdot \text { plant }^{-1}\right)\end{array}$ \\
\hline \multicolumn{4}{|c|}{ Burn x Clipping Height } \\
\hline $\begin{array}{l}5-\mathrm{cm} \\
5 \text { urned }\end{array}$ & $24 \mathrm{a}^{2}$ & $44 \mathrm{a}$ & $9.6 \mathrm{a}$ \\
\hline $15-\mathrm{cm}$ & $26 \mathrm{a}$ & $43 \mathrm{a}$ & $8.8 \mathrm{a}$ \\
\hline Undefoliated & 23 & 46 & 9.7 \\
\hline Pooled Mean & 25 & 44 & 9.3 \\
\hline \multicolumn{4}{|l|}{ Non-burned } \\
\hline $5-\mathrm{cm}$ & $39 \mathrm{~b}$ & $122 \mathrm{~b}$ & $15.3 \mathrm{~b}$ \\
\hline $15-\mathrm{cm}$ & $46 \mathrm{a}$ & $153 \mathrm{a}$ & $22.4 \mathrm{a}$ \\
\hline Undefoliated & 46 & 172 & 20.1 \\
\hline Pooled Mean & 43 & 143 & 19.0 \\
\hline Interaction $\mathrm{SE}$ & 1 & 0.6 & 1.4 \\
\hline \multicolumn{4}{|c|}{ Burn $x$ Season of Clipping } \\
\hline \multicolumn{4}{|c|}{ Burned } \\
\hline May & 25 & 47 & $11.5 \mathrm{a}$ \\
\hline July & 23 & 38 & $6.5 \mathrm{a}^{3}$ \\
\hline September & 22 & 45 & $9.6 \mathrm{a}$ \\
\hline \multicolumn{4}{|l|}{ Non-burned } \\
\hline May & 38 & 132 & $19.5 \mathrm{a}$ \\
\hline July & 43 & 144 & $20.3 \mathrm{a}$ \\
\hline September & 39 & 137 & $16.7 \mathrm{a}$ \\
\hline Interaction SE & 1 & 0.8 & 1.7 \\
\hline
\end{tabular}

Aboveground net primary production.

${ }^{2}$ Within a column and burn treatment, means followed by the same letter do not differ significantly $(\mathrm{P}>0.05)$.

${ }^{3}$ Burned July plant ANPP differs from May $(0.05<\mathrm{P}<0.10)$ within burned and non-burned plants defoliated in September were also similar to the non-defoliated controls for both burned (207 vs 195, respectively) and nonburned (118 vs 114 , respectively) plants.

Additional effects were observed of burning and defoliation season on inflorescence production $(P=0.04)$ in 2000 . Defoliation in July resulted in the greatest reduction of inflorescences (Fig. 2), but was most apparent within non-burned plants. Notably, inflorescence production also appeared to increase within the September defoliated plants in both burned and non-burned plants relative to the unde- 


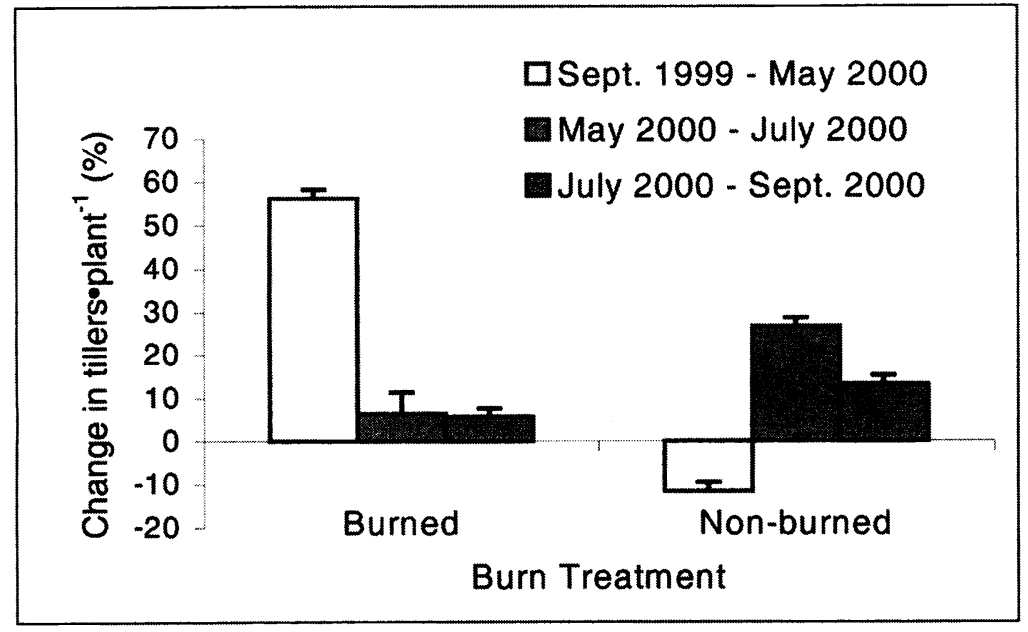

Fig. 1. Seasonal changes in tiller numbers $( \pm$ SE) from September 1999 to September 2000 on burned and non-burned plants following a spring wildfire in $1999(n=8)$. Changes in tiller number were affected $(P<0.0001)$ by the measurement interval and the burning treatment as evaluated by multivariate analysis of variance for repeated measures.

foliated controls (Fig. 2). In contrast, clipping intensity had no effect $(\mathrm{P}>0.05)$ on inflorescence production (Table 4).

Finally, burned plants had $44 \%$ less etiolated growth of tillers compared to nonburned plants (Table 6), and May defoliation the previous year resulted in significantly less $(P<0.05)$ etiolated growth at both the tiller and plant level (Table 6). The effect of defoliation intensity and season, however, were similar $(\mathrm{P}>0.05)$ between burned and non-burned plants.

\section{Discussion}

\section{Response to Burning}

Foothills rough fescue plants had reduced yields the first and second growing seasons after spring burning, which is comparable to Redmann et al. (1993) and Gerling et al. (1995) for plains rough fescue. The yield reductions in the present study were related to burning resulting in shorter, lighter tillers, and occurred despite a 50\% increase in tiller numbers in burned plants during the second year. These results indicate that tiller recruitment by burning could not compensate for depressed tiller weights over the 2 years of monitoring conducted here. This pattern may be related to re-allocation of limited plant resources such as carbohydrates to a greater number of tillers, particularly as they become larger with age throughout the growing season, post-burn conditions related to litter removal (Redmann 1978, Savage 1980) and precipitation.
Precipitation during the first growing season after fire was near average, however, precipitation to the end of the second growing season was only about $54 \%$ of the long-term average (Table 1). Reduced precipitation may have limited plant growth in the second year. Given the loss of litter with burning and its importance for growth (Willms et al. 1986), moisture deficits were also likely exacerbated by the fire.

Although burning decreased plant ANPP, height and inflorescence production, suggesting a negative response to burning, a more reliable indicator of plant response may be tiller numbers as it represents longer-term productive potential. Using tiller numbers as a standard, burning may have improved plant vigor by stimulating tillering, thereby supporting the notion that rough fescue is both adapted to, and the beneficiary of, fire. Coincident changes in etiolated growth, however, showed no effect $(\mathrm{P}>0.05)$ of burning on the plant but a reduction for individual tillers (Table 6). Etiolated growth is positively correlated with carbohydrate levels in the roots and crowns of grasses (Raese and Decker 1966, Dorvat et al. 1972). The reduction in energy at the tiller level in burned plants suggests some susceptibility to further damage should tiller development be impeded. Burning foothills rough fescue has been shown to increase individual plant production 3 years after wildfire, but increased plant mortality of burned plants resulted in lower total fescue production compared to non-burned areas (Antos et al. 1983).
Therefore, enhanced tiller numbers following burning are likely to benefit future production only when plant mortality is limited. No mortality was documented in the current study.

Although the results here focus on rough fescue plants, their response is not necessarily indicative of the entire grassland because the reproductive capacity of many plant species are uniquely adapted to filling ecological niches in the post-fire environment. Increased forb biomass after a late winter wildfire helped compensate for a reduction in grass production by the second year after burning in a grassland similar to the present study (Bork et al. 2002).

\section{Response to Post-Burn Defoliation}

Given that post-burn grazing of regrowth by wildlife was likely common prior to European settlement, the postulation might be made that rough fescue can tolerate this pattern of disturbance. However, the decision to graze with livestock in the year after burning might be based as much on the benefits to animals as on the effect to the plant. By May, the time when grazing normally begins on Fescue Prairie, burned plants had produced only $5 \%$ the biomass of non-burned plants, which subsequently increased to only $40 \%$ by September. Thus, available forage for grazing declined markedly with burning.

Results indicate that clipping of burned plants in early spring did not produce a cumulative negative effect on plant recovery. Burning appeared to increase plant resilience to post-burn harvesting by slowing growth and minimizing exposure of regrowth to defoliation. Nevertheless, plant energy reserves were lowest in

Table 6. Effects of spring wildfire and subsequent date of defoliation in 1999 on the ANPP $^{1}$ of etiolated tillers and plants in May 2000.

\begin{tabular}{lcc}
\hline \hline Plant & Treatment & Tiller \\
\hline \multicolumn{2}{c}{$\left(\mathrm{mg} \bullet\right.$ tiller $\left.^{-1}\right)$} & $\left(\mathrm{g} \bullet\right.$ plant $\left.^{-1}\right)$ \\
Burn Treatment $(\mathrm{n}=12)$ & & \\
$\quad$ Burned & 9.0 & 1.6 \\
$\quad$ Non-burned & 16.2 & 1.8 \\
$\quad$ SE mean & 1.8 & 0.23 \\
Season of Clipping $(\mathrm{n}=8)$ & & \\
$\quad$ May & $7.4 \mathrm{~b}^{2}$ & $1.2 \mathrm{~b}$ \\
$\quad$ July & $14.0 \mathrm{ab}$ & $1.5 \mathrm{ab}$ \\
$\quad$ September & $16.3 \mathrm{a}$ & $2.5 \mathrm{a}$ \\
$\quad$ SE mean & 2.2 & 0.28 \\
Undefoliated Control & & \\
(n=4) & 16.3 & 1.5 \\
\hline
\end{tabular}

Aboveground net primary production.

${ }^{2}$ Within a column and burn treatment, means followed by the same letter do not differ significantly $(P>0.05)$. 


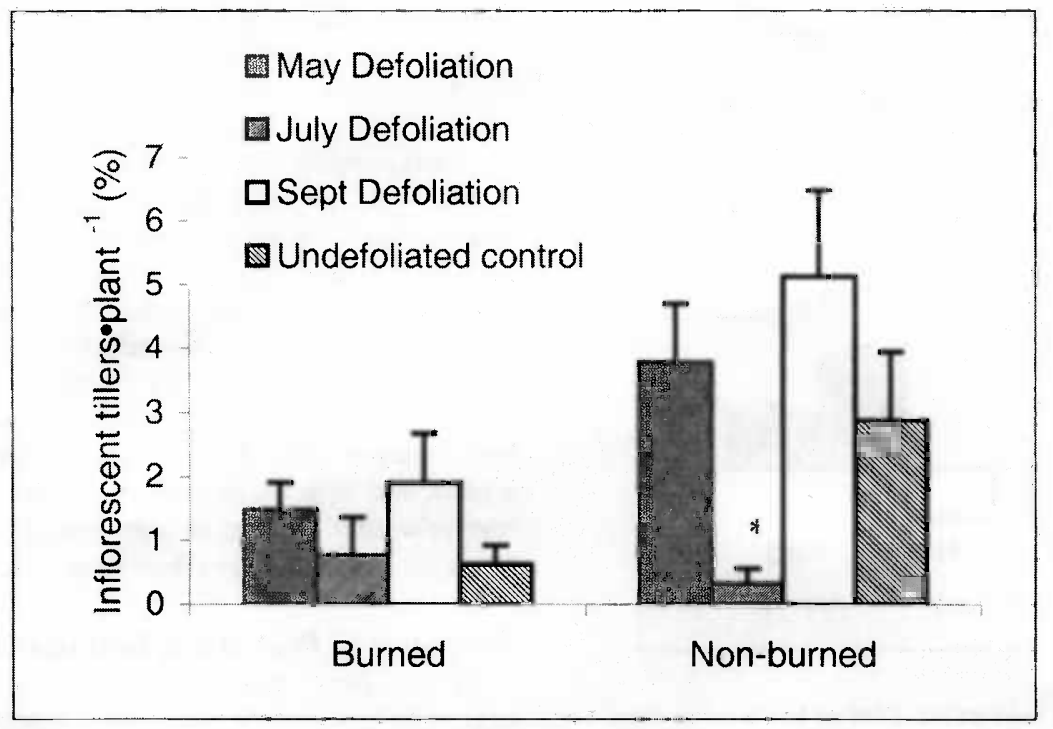

Fig. 2. Changes in the proportion of inflorescences $( \pm \mathrm{SE})$ in July, 2000 on burned and nonburned plants following a spring wildfire in 1999 and subsequent defoliation at 3 dates $(\mathrm{n}=$ 8). Within the unburned treatments, the July clipping (denoted with a *) differs from May and September $(\mathbf{P}<\mathbf{0 . 0 5})$.

plants defoliated the previous year in May (Table 6), regardless of their burn status, which indicates vulnerability to spring grazing and supports the commonly held belief that grazing should be delayed in spring to benefit plant vigor. Burned plants of Idaho fescue had greater mortality when defoliated in early summer compared to early fall (Bunting et al. 1998). Although plants tend to become more vulnerable to defoliation at the time of inflorescence development (i.e., July) due to the re-allocation of energy to seed production (Branson 1953), rough fescue plants in this study produced very few inflorescences relative to the total number of tillers (Fig. 2). Inflorescence production in 2000, however, did exhibit a general reduction the following year within plants defoliated the previous July (Fig. 2). This observation, coupled with a marginal trend towards a decline in plant ANPP (Table 5) and a marked reduction in tiller numbers within burned plants defoliated during July, suggests deferral of grazing beyond inflorescence development is warranted, particularly if plant recruitment is desired.

In contrast to the season of defoliation, severity of defoliation had no effect $(\mathrm{P}>$ 0.05 ) on any plant response variable measured within burned plants. Burned plants had a linear pattern of growth from May to September, which may indicate that sufficient photosynthetic tissue remained after severe defoliation to restore the plant energy requirements under conditions favorable for growth in the first year.
More severe defoliation of non-burned plants, particularly those defoliated at 5 $\mathrm{cm}$, resulted in declines in height as well as tiller and plant ANPP 1 year after defoliation. The different response to clipping between burned and non-burned plants may be partly related to the relative proportion of herbage removed from plants and the photosynthetic area remaining after clipping. Clipping at a fixed height will remove a greater proportion of total herbage from tall, rapidly growing nonburned plants compared with shorter, burned plants, and likely accounts for the differing phytomass levels harvested in 1999. This resulted in clipped, non-burned plants having greater treatment differences than burned plants. Similar mechanisms have been suggested for the effect of water stress on subsequent defoliation in grasses (Simone and Baruch 1991), and highlights a limitation of the common practice of using fixed clipping heights as a replacement for actual grazing.

Morphological differences in burned and non-burned plants may also be important. Unlike burned plants, tiller sheaths in nonburned plants remained intact below the height of defoliation, shielding the enclosed leaf tissue. Clipping at $15 \mathrm{~cm}$, however, may still leave some photosynthetic surface exposed. Additionally, the clipping height of $5 \mathrm{~cm}$ used in this investigation represents a relatively severe defoliation, which livestock grazing may only achieve when stubble had previously been removed by burning or severe grazing.
It should be noted that the single defoliation treatment we applied more closely simulates the effect of short duration or high intensity-low frequency grazing rather than season-long grazing. Multiple harvests during the growing season, as might occur under season-long grazing, has been shown to severely reduce yields of rough fescue plants and increase mortality (Willms and Fraser 1992). However, the results found here do support the findings of Willms (1991) suggesting that the effects of defoliation on plant yield may only be fully evident in the second year after treatment.

Plant responses to burning or defoliation are also dependent on previous disturbances. In our study, individual fescue plants had a long history of protection from grazing, which was likely to produce stability within plant vigor and its local environment. Although tiller demographics have not been documented for rough fescue, it appears that individual tillers can be several years old prior to producing an inflorescence. In our study, very few plants produced inflorescences in either year and tillers became more robust over time. Therefore, it is likely that initial disturbances have the greatest impact in upsetting the energy dynamics within fescue plants, while the effect of subsequent disturbance is dependent on factors such as recovery time. In our study, clipping represented the initial disturbance of nonburned plants and could be expected to have a greater effect than in slower growing burned plants.

Tillering is perhaps the most important response to disturbance as it determines the future potential productivity within the plant (Murphy and Briske 1992). Both burning and clipping increased overall tiller numbers, which implies enhanced productive potential. However, this trend also coincided with a decline in the potential for sexual reproduction, as evidenced by a decrease in the proportion of inflorescent tillers. July defoliation appeared to be particularly detrimental, reducing the proportion of seedheads 1 year later from about $5 \%$ to less than $1 \%$ of all tillers, indicating longer-term impacts due to defoliation can occur on sexual recruitment within rough fescue.

\section{Management Implications}

Although burning may impede various aspects of development in foothills rough fescue plants, it also represents a potential mechanism for plant renewal through 
enhanced tiller production. Its also appears that spring burned fescue plants can be safely grazed in a single defoliation event during the early part of the first growing season if the environmental conditions are favorable for recovery. This tolerance is probably linked to slow plant growth limiting the impact of subsequent defoliation. Despite this, limited available forage from burned plants may not warrant the potential risk to the plant under most grazing systems as burning could facilitate grazing close to the crown and lead to a loss of plant vigor. In addition, burned plants appear to increase in sensitivity to July defoliation during the post-burn recovery growing season, potentially due to a delay in plant growth coinciding with burninduced stress. In conclusion, both plant physiological (carbohydrate) and morphological (height, ANPP, tillers, and inflorescence) characteristics exhibited marked responses into the second year following burning and defoliation, suggesting that the risk associated with grazing burned fescue plants may be greater than any potential benefits in the short-term. Finally, these results also highlight the importance of longer-term monitoring and management to maximize the recovery of foothills rough fescue plants exposed to defoliation or fire.

\section{Literature Cited}

Anderson, H.G. and A.W. Bailey. 1980. Effects of annual burning on grassland in the aspen parkland of east-central Alberta. Can. J. Bot. 58:985-996.

Antos, J.A., B. McCune, and C. Bara. 1983. The effect of fire on an ungrazed western Montana grassland. Amer. Midl. Nat. 110:354-364.

Bailey, A.W. and M.L. Anderson. 1978. Prescribed burning of a Festuca-Stipa grassland. J. Range Manage. 31:446-449.
Barker, W.T. and D.O. Erickson. 1971. The effects of burning and mowing on utilization. J. Anim. Sci. 39:985.

Bork, E.W., B. Adams, and W. Willms. 2002. Resilience of Festuca campestris (Rydb.) rangeland to wildfire. Can. Field Natur. 116:51-59.

Branson, F.A. 1953. Two factors affecting resistance of grasses to grazing. J. Range Manage. 6: 165-171.

Bunting, S.C., R. Robberecht, and G.E. Defosse. 1998. Length and timing of grazing on postburn productivity of two bunchgrasses in an Idaho experimental range. Int. J. Wildl. Fire 8:15-20.

Dormaar, J.F. and W.D. Willms. 1990. Sustainable production from the Rough Fescue Prairie. J. Soil Water Conserv. 45:137-140.

Dorvat, A., B. Deinum, and J.G.P. Dirven. 1972. The influence of defoliation and nitrogen on the regrowth of Rhodes grass (Chloris gayana Kunth). 2. Etiolated growth and nonstructural carbohydrate, total-N and nitrate- $\mathrm{N}$ content. Neth. J. Agr. Sci. 20:97-103.

Gerling, H.S., A.W. Bailey, and W.D. Willms. 1995. The effects of burning on Festuca hallii in the parklands of central Alberta. Can. J. Bot. 73:937-942.

Jourdonnais, C.S. and D.J. Bedunah. 1990. Prescribed fire and cattle grazing on an elk winter range in Montana. Wildl. Soc. Bull. 18: 232-240.

Looman, J. 1969. The fescue grasslands of western Canada. Vegetatio, 19:128-145.

Murphy, J.S. and D.D. Briske. 1992. Regulation of tillering by apical dominance: chronology, interpretive value, and current perspectives. J. Range Manage. 45: 419-429.

Pavlick, L.E. and J. Looman. 1984. Taxonomy and nomenclature of rough fescues, Festuca altaica, $F$. campestris ( $F$. scabrella var. major), and $F$. hallii, in Canada and the adjacent part of United States. Can. J. Bot. 62:1739-1749.

Raese, J.T and A.M. Decker. 1966. Yields, stand persistence, and carbohydrate reserves of perennial grasses as influenced by spring harvest, stubble height, and nitrogen fertilization. Agron. J. 58:322-326.
Redmann, R.E. 1978. Plant and soil water potentials following fire in a northern mixed grassland. J. Range Manage. 31:443-445.

Redmann, R.E., J.T. Romo, and B. Pylypec. 1993. Impacts of burning on primary productivity of Festuca and Stipa-Agropyron grasslands in central Saskatchewan. Amer. Midl. Nat. 130:262-273.

SAS Institute Inc. 1991. SAS system for linear models. $3^{\text {rd }}$ ed., SAS Institute Inc., Cary, N.C.

Savage, M.J. 1980. The effect of fire on the grassland microclimate. Herb. Abstr. 50:589-603.

Simones, M.. and Z. Baruch. 1991. Responses to simulated herbivory and drought in two tropical $\mathrm{C}_{4}$ grasses. Oecologia, 88:173-180.

Steel, R.G.D., J.H. Torrie, and D.A. Dickey. 1997. Principles and procedures of statistics: A biometrical approach, $3^{\text {rd }}$ ed. McGrawHill, New York.

Strong, W.L. and K.R. Leggat. 1992. Ecoregions of Alberta: Volume 1. Alberta Forestry, Lands, \& Wildlife, Land Info. Services, Edmonton.

Willms, W.D. 1991. Cutting frequency and cutting height effects on rough fescue and Parry oat grass yields. J. Range Manage. 44:82-86.

Willms, W.D. and J. Fraser. 1992. Growth characteristics of rough fescue (Festuca scabrella var. campestris) after three years of repeated harvesting at scheduled frequencies and heights. Can. J. Bot. 70:2125-2129.

Willms, W.D., S. Smoliak, and A.W. Bailey. 1986. Herbage production following litter removal on Alberta native grasslands. J. Range Manage. 39:536-540.

Willms, W.D., S. Smoliak, and J.F. Dormaar. 1985. Effects of stocking rate on a rough fescue grassland vegetation. J. Range Manage. 38:220-225.

Wright, H.A. 1974. Range burning. J. Range Manage. 27:5-11.

Wroe, R.A. 1972. Alberta range condition and stocking rate guide. Alberta Dep. of Land and Forest Serv. Edmonton, Alberta. 